\title{
Shark liver oil consumption decreases contractility in EDL muscle of trained rats
}

\author{
O consumo de óleo de fígado de tubarão reduz a \\ contratilidade do músculo EDL em ratos treinados
}

El consumo de aceite de hígado de tiburón reduce la
contractilidad del músculo EDL en ratones entrenados

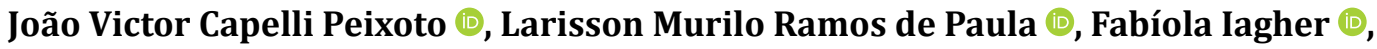

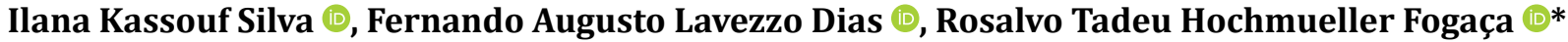

Universidade Federal do Paraná (UFPR), Curitiba, PR, Brazil

Abstract

Introduction: Professional and recreational athletes make daily use of nutritional supplements to improve physical performance. Polyunsaturated fatty acids (PUFAs) have been used in this sense. N-3 PUFA, particularly eicosapentaenoic (EPA) and docosahexaenoic (DHA) acids are involved in important physiological functions and the benefits of supplementation are demonstrated in several types of users. Shark liver oil (SLO) is a natural source of n-3 PUFA. Objective: To evaluate the effect of supplementation with SLO on contractility of skeletal muscles with different metabolic characteristics, soleus and extensor digitorum longus (EDL) from

* JVCP: Doctoral student, e-mail: jjpeixoto83@gmail.com LMRP: Master's student, e-mail: nutricionistalarisson@gmail.com FI: PhD, e-mail: fabiolaiagher@gmail.com IKS: PhD, e-mail: ikassouf@ufpr.br FALD: PhD, e-mail: fernandoaldias@gmail.com RTHF: PhD, e-mail: fogaca@ufpr.br 
rats submitted to eight weeks of interval training of progressive intensity on a motorized treadmill. In the supplemented group, animals were supplemented with SLO (1 g/kg) five times a week for eight weeks. Method: Contractile parameters as maximum isometric twitch force (Tmax), maximum speed of force development $(+\mathrm{dF} /$ $\mathrm{dt}$ ), maximum speed of force decrease (-dF/dt), maximum tetanic force (Fmax) and resistance to fatigue were analyzed in isolated muscle. Results: Compared to the control group, EDL muscles from the supplemented group reduced Tmax at the first $\left(10.82 \pm 0.89\right.$ vs $\left.14.30 \pm 0.67 \mathrm{mN} / \mathrm{mm}^{2} . \mathrm{p}<0.01\right)$ and second minutes of experimentation ( $9.85 \pm 0.63$ vs $\left.13.12 \pm 0.70 \mathrm{mN} / \mathrm{mm}^{2} . \mathrm{p}<0.01\right)$. However, it increased resistance to fatigue $(22.80 \pm 0.97$ vs $18.60 \pm 0.51$ seconds. $p=0.005)$. Conclusion: No difference was observed in the soleus muscle.

Keywords: N-3 PUFA. Treadmill. Exercise. Rats. Skeletal Muscle.

\section{Resumo}

Introdução: Atletas profissionais e recreativos utilizam suplementos nutricionais diariamente para melhorar a performance física. Os ácidos graxos poliinsaturados (PUFA) têm sido usados nesse sentido. Os n-3 PUFA, particularmente os ácidos eicosapentaenoicos (EPA) e docosaexaenoico (DHA), são relacionados com importantes funções fisiológicas e os benefícios da suplementação são demonstrados em diversas populações. O óleo de fígado de tubarão (OFT) é fonte natural de n-3 PUFA. Objetivo: Avaliar o efeito da suplementação com OFT na contratilidade de músculos esqueléticos com diferentes características metabólicas, sóleo e extensor longo de dedos (EDL) de ratos submetidos a oito semanas de treinamento intervalado de intensidade progressiva em esteira motorizada. No grupo suplementado, os animais foram suplementados com OFT $(1 \mathrm{~g} / \mathrm{kg}$ ) cinco vezes por semana por oito semanas. Método: Parâmetros contráteis como produção de força isométrica máxima (Tmax), velocidade máxima de contração $(+d F / d t)$, velocidade máxima de relaxamento ( $-d F / d t)$, força tetânica máxima (Fmax) e resistência à fadiga foram analisados em músculos isolados. Resultados: Comparados ao grupo controle, os músculos EDL dos animais do grupo suplementado reduziram Tmax no primeiro (10.82 $\pm 0.89 \mathrm{vs} 14.30 \pm 0.67 \mathrm{mN} / \mathrm{mm} 2$. $p<0.01) e$ no segundo minutos de experimentação (9.85 \pm 0.63 vs $13.12 \pm 0.70 \mathrm{mN} / \mathrm{mm} 2 . p<0.01)$, entretanto, aumentaram a resistência à fadiga (22.80 \pm 0.97 vs $18.60 \pm 0.51$ segundos. $p=0.005)$. Conclusão: Nenhuma diferença foi observada no músculo sóleo.

Palavras-chave: N-3 PUFA. Esteira Motorizada. Exercício. Ratos. Músculo Esquelético.

\section{Resumen}

Introducción: Los atletas profesionales y recreativos utilizan suplementos nutricionales diariamente para mejorar el rendimiento físico. Los ácidos grasos poliinsaturados (PUFA) se han utilizado en este sentido. Los n-3 PUFA, particularmente los ácidos eicosapentaenoicos (EPA) y el docosaexáenoico (DHA), se relacionan con importantes funciones fisiológicas y los beneficios de la suplementación se demuestran en diversas poblaciones. El aceite de hígado de tiburón (AHT) es fuente natural de n-3 PUFA. Objetivo: Evaluar el efecto de la suplementación con AHT en la contractilidad de músculos esqueléticos con diferentes características metabólicas, sololeo y extensor largo de dedos (EDL) de ratas sometidas a ocho semanas de entrenamiento intervalado de intensidad progresiva en estera motorizada. En el grupo suplementario, los animales fueron suplementados con AHT $(1 \mathrm{~g} / \mathrm{kg})$ cinco veces por semana durante ocho semanas. Método: Parámetros contráctiles como producción de fuerza isométrica máxima (Tmax), velocidad máxima de contracción ( $+d F / d t)$, velocidad máxima de relajación ( $-d F / d t)$, fuerza tetánica máxima (Fmax) y resistencia a la fatiga se analizaron en músculos aislados. Resultados: En comparación con el grupo control, los músculos EDL de los animales del grupo suplementado redujeron Tmax en el primer (10.82 $\pm 0.89 \mathrm{vs} 14.30 \pm 0.67 \mathrm{mN} /$ mm2. $p<0.01$ ) y en el segundo minuto de experimentación (9.85 \pm 0.63 vs $13.12 \pm 0.70 \mathrm{mN} / \mathrm{mm} 2$. $p<0.01)$, sin embargo, aumentaron la resistencia a la fatiga (22.80 \pm 0.97 vs $18.60 \pm 0.51$ segundos. $p=0.005)$. Conclusión: No se observó ninguna diferencia en el músculo sóleo.

Palabras clave: N-3 PUFA. Estera Motorizada. Ejercicio. Ratas. Músculo Esquelético. 


\section{Introduction}

Professional and recreational athletes make daily use of nutritional supplements to improve physical performance, increase hypertrophy, and reduce fatigue and the interval between training sessions. In addition, high intensity exercises are known to be physiologically demanding and sometimes reduce the immune function of practitioners [1]. Therefore, there is constant search for supplements that sustain the training program without detriment to health.

Polyunsaturated fatty acids (PUFAs) have been used in this sense [2]. N-3 PUFA, particularly, eicosapentaenoic (EPA) and docosahexaenoic (DHA) acids are involved in important physiological functions related to immunomodulatory $[3,4]$ and anti-inflammatory [5, 6] properties. They can be found in marine sources such as oily fish, crustaceans and liver of lean fish that are rich in EPA and DHA. As it is not synthesized by the body, consumption of n-3 PUFA is important to provide the body with necessary amounts of EPA and DHA [7]. Shark liver oil (SLO) is a natural source of n-3 PUFA. The fatty acid profile of SLO reveals the presence of DHA (10 to 18\%) and EPA (5 to 16\%) [8]. These concentrations vary depending on the animal species caught and their sources of feed [9]. In skeletal muscle, the benefits of supplementation were described to reduce dynapenia [10], improve muscle mass and function in general $[11,12]$.

The skeletal muscle fiber types are mainly classified by the predominant Myosin Heavy Chain (MHC) isoform, but also by the isoform and content of proteins involved with the molecular machinery responsible for $\mathrm{Ca}^{++}$cycle (release and reuptake of $\mathrm{Ca}^{++}$by the Sarcoplasmic Reticulum (SR)) [13]. In order to sustain the metabolic and mechanical demand of physical exercise, muscles with different predominance of fiber types are recruited according with the intensity and duration of the activity [14].

Prior to muscle contraction, the ExcitationContraction Coupling (ECC) culminates in the release of $\mathrm{Ca}^{++}$from the $\mathrm{SR}$ to the sarcoplasm [13]. In the sarcoplasm, $\mathrm{Ca}^{++}$binds to troponin $\mathrm{C}$, allowing the cross-bridge cycle, shortening of sarcomeres and force production associated to ATP hydrolysis [13]. The rate of ATP hydrolysis and ADP dissociation from the ATPase enzyme at the head of myosin is what classifies the MHC isoforms as fast, slow or intermediate [15]. Type I MHC is mainly expressed in slow twitch fibers, with large content of mitochondria and oxidative enzymes, characteristics that make them resistant to fatigue. Type IIb and IIx MHC are mainly expressed in fast twitch fibers, with glycogen stores and a large amount of glycolytic enzymes, which classified them with power characteristics, but quickly fatigued and, type IIa MHC is intermediate and has characteristics of both fast and slow fibers [15]. For muscle relaxation, sarcoplasmic $\mathrm{Ca}^{++}$is uptaken by the sarco endoplasmic $\mathrm{Ca}^{++}$ATPase (SERCA) to the $\mathrm{SR}$, decreasing free $\mathrm{Ca}^{++}$concentration, interrupting cross-bridges cycle and force production [13].

In healthy and sedentary rats, the extensor digitorum longus (EDL) consists of a mean of $20 \%$ type IIa fibers, 38\% type IIx fibers and 38\% type IIb fibers, which makes it a muscle with glycolytic and therefore, power characteristics. On the contrary, soleus consists of $84 \%$ type I fibers, $7 \%$ type IIa fibers and 9\% type IIx fibers, which makes it a muscle with oxidative and therefore, resistance characteristics [16].

Notwithstanding, SLO is known to have two types of lipids with proven action on the immune system [3-6] and n-3 PUFA supplementation may impact muscle metabolism [10-12]. However, there is a lack of data assessing its impact on muscle contractility and resistance to fatigue in different muscle types, and this investigation could bring new evidence to support the use of n-3 PUFA supplementation in a population that practices physical activities aiming to improve the athletic performance. Thus, the objective of this study is to evaluate the effect of eight weeks supplementation with SLO on the contractile mechanics of skeletal muscles with different metabolic characteristics, soleus and EDL, isolated from rats submitted to interval training of progressive intensity on a motorized treadmill.

\section{Methods}

\section{Animals}

Fourteen male Wistar rats, weighing 250 g-300 g were used. Animals were kept in cages under controlled conditions of temperature and light-dark cycle of $12 \mathrm{~h}$, with free access to food and water. The 
Animal Experimentation Ethics Committee of the Biological Sciences Section at Federal University of Paraná approved all experimental protocols used in this study (AEEC-966).

Rats were randomly separated into two groups: a control group ( $C G, n=7$ ) and a supplemented group (SG, $n=7$ ). Animals from the $C G$ were adapted to treadmill training and performed the training protocol three times a week for eight weeks. The animals from the SG, after being adapted to treadmill training, began to be supplemented with SLO (Naturalis Alimentos Naturais Ltda, São Paulo, Brazil) by gavage $(1 \mathrm{~g} / \mathrm{kg})$ five times a week for eight weeks and performed the training protocol three times a week for eight weeks.

\section{Adaptation to training and protocol of exhaustion}

In the first week the animals were adapted to exercise for five consecutive days, two sessions per day with a five-minute rest interval between sessions. The treadmill was maintained with a 5-degree slope for all sessions.

On the first day the animals walked 10 minutes at $5 \mathrm{~m} / \mathrm{min}$, and there was a rest interval of 5 minutes, followed by 20 minutes at $5 \mathrm{~m} / \mathrm{min}$. On the second day, 10 minutes at $7 \mathrm{~m} / \mathrm{min}$, a 5 -minute rest interval followed by 20 minutes at $7 \mathrm{~m} / \mathrm{min}$. On the third day, 15 minutes at $10 \mathrm{~m} / \mathrm{min}$, 5 -minute rest interval followed by 20 minutes at $10 \mathrm{~m} / \mathrm{min}$. On the fourth day, 15 minutes at $12 \mathrm{~m} /$ min, 5-minute rest interval followed by 20 minutes at $12 \mathrm{~m} / \mathrm{min}$. Finally, on the fifth day, 20 minutes at $15 \mathrm{~m} / \mathrm{min}, 5$-minute rest interval followed by 20 minutes at $15 \mathrm{~m} / \mathrm{min}$.

On the sixth day the animals were submitted to an exhaustion protocol aiming to identify the maximum capacity of each animal. It was done as follows: two minutes warming up at $5 \mathrm{~m} / \mathrm{min}$, followed by an increase in speed of 2 meters per minute every 2 minutes. When the animal could not maintain the speed for two minutes, the previous speed at $100 \%$ was considered. The adaptation to training and exhaustion protocol was adapted from previous published methods by Wisloff et al. [17].

\section{Exercise protocol}

The physical exercise sessions started 48 hours after the exhaustion test, and were performed
3 times a week for 8 weeks. The exercise was intermittent with progressive intensity, starting with 5 minutes at a speed corresponding to $50 \%$ of the maximum capacity, followed by 3 minutes of passive rest. The exercise was restarted for 5 minutes at $60 \%$ of the maximum capacity, followed by 3 minutes of passive rest, and so on at $70 \%, 80 \%$, $90 \%$ and $100 \%$ of the maximum capacity. Finally, the cool down period was performed at $50 \%$ of maximal capacity for 3 minutes. Each session totalized 30 minutes of exercise and 15 minutes of rest. The exercise protocol was adapted from Haram et al. [18]. After 48 hours from the last training session, the animals were euthanized by decapitation and the following protocols were performed:

Contractile measurements of soleus and EDL muscle in vitro:

The animals were euthanized, soleus and EDL muscle were removed, dissected and kept in Ringer's solution. This solution had the following composition: $\mathrm{NaCl} 110 \mathrm{mM}, \mathrm{KCl} 4 \mathrm{mM}, \mathrm{CaCl}_{2}$ $2 \mathrm{mM}, \mathrm{MgCl}_{2} 2 \mathrm{mM}$, TRIZMA $10 \mathrm{mM}$ and glucose $11 \mathrm{mM}, \mathrm{pH}$ adjusted to 7.4 with $\mathrm{NaOH}$ or $\mathrm{HCl}$, gassed with pure oxygen and maintained at $37^{\circ} \mathrm{C}$. As described by Ryall et al, [19], one tendinous portion of the muscle was fixed to a stationary clip while the other tendinous portion was attached to a force transducer (Fort 10 WPI, Transduction Laboratories Co.) to measure contractions under isometric conditions. For soleus, optimum muscle length (Lo) was determined from the length at which the isometric twitch force was maximal. For EDL, before starting the protocol, single electrical stimuli in different muscle length were performed. The length at which a single twitch was maximal was considered Lo. Muscles were stretched through a micro manipulator coupled to the stationary clip. Electrical stimulation was performed directly through two platinum electrodes positioned along the muscle in the bath chamber where the muscle remained immersed in Ringer's solution. Supralimiar voltage ( $8 \mathrm{~V}$ for soleus and $24 \mathrm{~V}$ for EDL) with one millisecond pulse and standard frequency of 0.5 hertz were applied during six minutes to evaluate contractile endurance. Parameters as maximum isometric twitch force (Tmax), maximum speed of force development $(+\mathrm{dF} / \mathrm{dt})$ and maximum speed of force decrease 
$(-\mathrm{dF} / \mathrm{dt})$ were recorded. At the end of the sixth minute, stimulus frequency was increased to 100 Hertz, where the maximum tetanic force (Fmax) and resistance to fatigue were recorded. Fatigue resistance was calculated as the time required to achieve a $50 \%$ reduction in maximum tetanic force. The cross-sectional area (CSA) was calculated using the formula: muscle mass/ [1.06 x (Lo x 0.44 for EDL or 0.71 for soleus)]. Tmax, $+\mathrm{dF} / \mathrm{dt},-\mathrm{dF} / \mathrm{dt}$ and Fmax were normalized by the CSA. Muscle contraction tractionates the force transducer, forming a digital record, collected by a PowerLab 4/30 (AD Instrument) acquisition system connected to a computer. Data were subsequently analyzed using a Lab Chart version 7.3.7 software.

\section{Statistical analysis}

Results are expressed as mean values with their standard errors of the mean. Student's t-test was used for single comparisons in the same experimental condition between groups. For multiple comparisons, two-way ANOVA followed by Bonfferoni's post hoc was used. GraphPad Prism 5 System (San Diego, CA, USA) was used for statistical analysis and plotting. A p-value lower than 0.05 was used as criterion for statistical significance.

\section{Results}

No differences were observed in the CSA of EDL between groups. The mean values in $\mathrm{mm}^{2}$ of CG $(n=7)$ and $S G(n=7)$ were: $1.45 \pm 0.09$ vs $1.39 \pm 0.04(p=0.587)$. Tmax is represented in figure 1A. Significant differences were observed at the first and second minutes of experimentation. The mean values in $\mathrm{mN} / \mathrm{mm}^{2}$ of CG and SG from the first to the sixth minute were: $14.30 \pm 0.67 \mathrm{vs}$ $10.82 \pm 0.89(\mathrm{p}<0.01) ; 13.12 \pm 0.70$ vs $9.85 \pm 0.63$ $(\mathrm{p}<0.01) ; 11.15 \pm 0.52$ vs $8.63 \pm 0.69$ $(p>0.05) ; 9.15 \pm 0.41$ vs $7.46 \pm 0.53$ $(\mathrm{p}>0.05) ; 7.63 \pm 0.35$ vs $6.46 \pm 0.41(\mathrm{p}>0.05) ;$ $6.63 \pm 0.19$ vs $5.81 \pm 0.38$ ( $\mathrm{p}>0.05)$.

$+\mathrm{dF} / \mathrm{dt}$ is represented in figure $1 \mathrm{~B}$. Significant differences were observed from the first to the fourth minute. The mean values in $\mathrm{mN} / \mathrm{mm}^{2} / \mathrm{s}$ of CG and SG from the first to the sixth minute were: $1072.46 \pm 43.77$ vs $807.23 \pm 39.94(\mathrm{p}<0.001)$; $1022.19 \pm 55.03$ vs $753.97 \pm 39.91(\mathrm{p}<0.001)$; $941.70 \pm 55.94$ vs $694.42 \pm 39.26(\mathrm{p}<0.001)$; $811.20 \pm 38.80$ vs $611.80 \pm 45.72(\mathrm{p}<0.01)$; $687.56 \pm 31.89$ vs $546.16 \pm 43.84(\mathrm{p}>0.05)$; $622.95 \pm 23.11$ vs $506.19 \pm 41.13(\mathrm{p}>0.05)$.

$-\mathrm{dF} / \mathrm{dt}$ is represented in figure 1C. Significant differences were observed at the first and second minute. The mean values in $\mathrm{mN} / \mathrm{mm}^{2} / \mathrm{s}$ of CG and SG from the first to the sixth minute were: $-446.94 \pm 33.72$ vs $-284.47 \pm 18.19$ $(\mathrm{p}<0.001) ;-340.21 \pm 37.19$ vs $-217.90 \pm 17.54$ $(\mathrm{p}<0.01) ;-264.59 \pm 30.43$ vs $-177.04 \pm 19.05$ ( $p>0.05) ;-207.22 \pm 22.16$ vs $-148.29 \pm 12.79$ ( $p>0.05) ;-164.61 \pm 21.70$ vs $-125.45 \pm 17.71$ ( $p>0.05) ;-146.97 \pm 21.80$ vs $-110.62 \pm 17.28$ $(\mathrm{p}>0.05)$.

No differences were observed between groups in Fmax. The mean values in $\mathrm{mN} / \mathrm{mm}^{2}$ of $\mathrm{CG}$ and SG were: $13.08 \pm 1.10$ vs $12.04 \pm 1.00(p=0.508)$.

The resistance to fatigue was analyzed by the time to reduce Fmax down to $50 \%$ and is represented in figure 1D. Significant differences were observed between groups. The mean values in seconds (s) of CG and SG were: $18.60 \pm 0.51$ vs $22.80 \pm 0.97$ $(\mathrm{p}=0.005)$.

For soleus, no differences were observed in the CSA between groups. The mean values in $\mathrm{mm}^{2}$ of CG $(\mathrm{n}=7)$ and $S G(\mathrm{n}=7)$ were: $1.19 \pm 0.06$ vs $1.27 \pm 0.11$ $(\mathrm{p}=0.529)$. Increasing voltage stimulation above $8 \mathrm{~V}$ did not increase Tmax, $+\mathrm{dF} / \mathrm{dt}$ or $-\mathrm{dF} / \mathrm{dt}$. At 0.5 hertz stimulation, the contractile parameters did not decrease over time. No differences were observed in the contractile parameters between groups. The mean values are in Table 1.

Table 1 - Soleus contractile parameters

\begin{tabular}{lccc}
\hline & CG & SG & p-value \\
\hline Tmax $\left(\mathrm{mN} / \mathrm{mm}^{2}\right)$ & $3.83 \pm 0.25$ & $4.21 \pm 0.42$ & 0.448 \\
$+\mathrm{dF} / \mathrm{dt}\left(\mathrm{mN} / \mathrm{mm}^{2} / \mathrm{s}\right)$ & $159.20 \pm 13.54$ & $154.69 \pm 15.33$ & 0.829 \\
$-\mathrm{dF} / \mathrm{dt}\left(\mathrm{mN} / \mathrm{mm}^{2} / \mathrm{s}\right)$ & $-42.72 \pm 2.01$ & $-47.24 \pm 5.98$ & 0.487 \\
Fmax $\left(\mathrm{mN} / \mathrm{mm}^{2}\right)$ & $22.99 \pm 1.03$ & $22.09 \pm 1.30$ & 0.598 \\
Resistance to fatigue $(\mathrm{s})$ & $194.14 \pm 20.71$ & $188.66 \pm 12.62$ & 0.833 \\
\hline
\end{tabular}

Note: $C G(n=7)$ and $S G(n=7) .{ }^{* \star}$ represents $p<0.01 .{ }^{* \star *}$ represents $p<0.001$. 


\section{Discussion}

This study demonstrated that SLO supplementation directly affects the contractile mechanics of EDL muscle, reducing maximum isometric twitch force, speed of contraction, speed of relaxation and increasing fatigue resistance. This is, to the best authors' knowledge, the first study to report such effects.

The goal ofinterval training is to develop fatigue [20]. As exercise intensity increases, mechanical load and metabolic disturbances due to muscle contraction trigger the activation of specific cell signaling pathways, as insulin growth factor signaling pathway (IGF-1) and mammalian target of rapamycin (MTOR), increasing protein synthesis, muscle size and strength [20]. Feed stimulus of high-fat diets are also able to activate cell signaling pathways [21]. In muscle cells, fatty acids bind to peroxisome proliferator activated receptor delta (PPARס), stimulating mitochondrial biogenesis via peroxisome proliferator receptor gamma co-activator-1alpha (PGC- $1 \alpha$ ) and converting glycolytic fibers into oxidative, altering the muscle phenotype [22, 23].

The experiments assessing contractility in this study demonstrated in EDL muscle a decrease in Tmax (Figure 1A), in $+d F / d t$ (Figure 1B) and in $-\mathrm{dF} /$ dt (Figure 1C) in the SG compared to the CG, despite an increase in resistance to fatigue (Figure 1D). This may represent changes in muscle fiber composition consequent to SLO supplementation.

Force generation depends on muscle size, number of cross-bridges in parallel and muscle trophism [24]. Significant decreases in Tmax at the first $(-24.3 \%)$ and second minutes $(-24.9 \%)$ were observed in EDL muscle from the SG. However, no difference was observed in CSA, which may indicate that the volume of contractile proteins in the muscles was maintained.
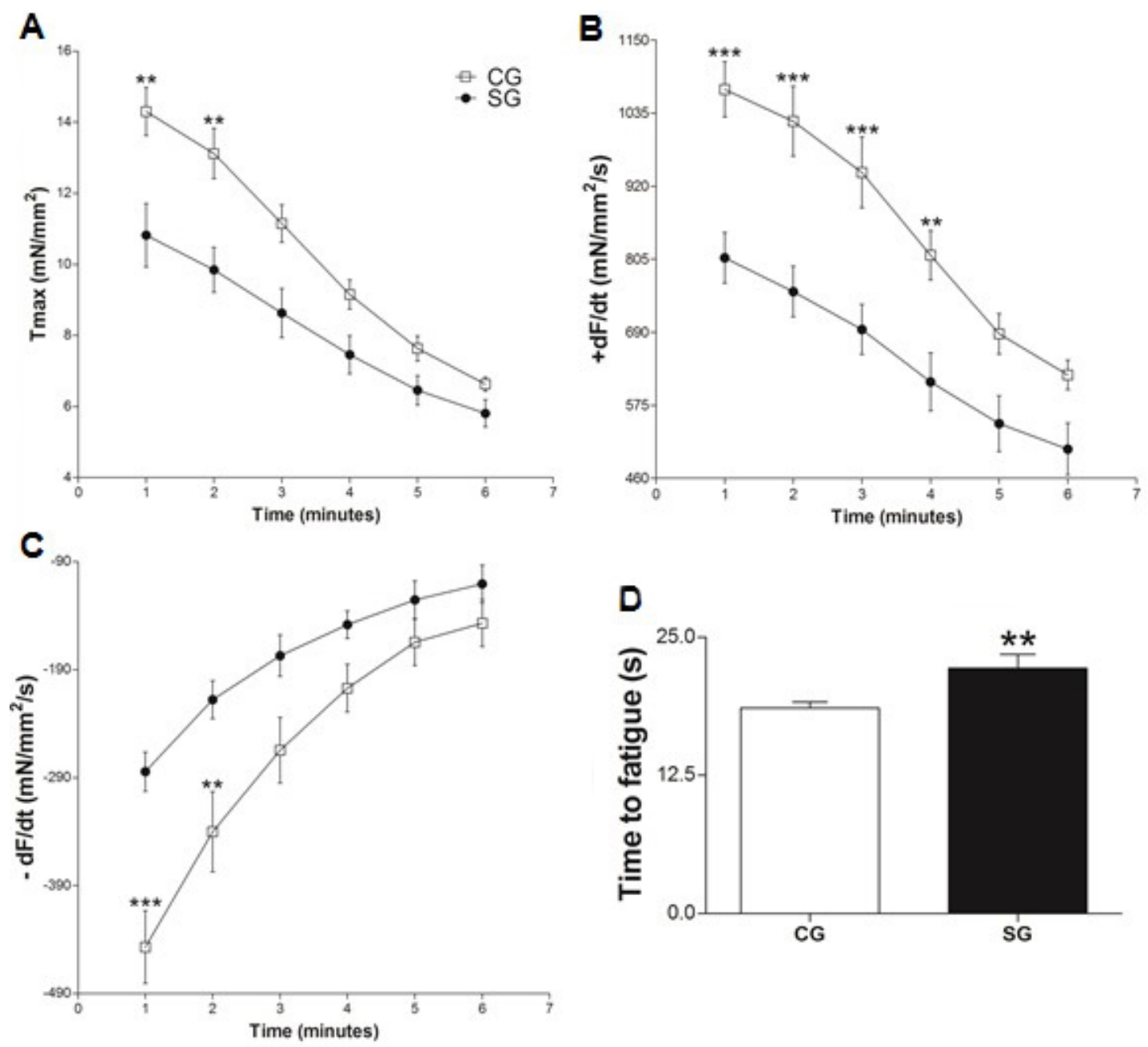

Note: A: Tmax; B: +dF/dt; C: -dF/dt; D: Resistance to fatigue. 
Figure 1-Contractile parameters from EDL muscles.

The speed of force development $(+\mathrm{dF} / \mathrm{dt})$ and of force decrease $(-\mathrm{dF} / \mathrm{dt})$ are determined mainly by the type of myosin present in the fiber [24], but also, by the content and isoform of proteins involved with the $\mathrm{Ca}^{++}$cycle in muscle cell [13]. Fast twitch fibers exhibit three to four times higher content of SERCA pump [25] and the $\mathrm{Ca}^{++}$cycle can occur up to seven times faster when compared to slow twitch fibers [13]. $+\mathrm{dF} / \mathrm{dt}$ in the SG EDL muscle, showed significant reduction at the first $(-24.7 \%)$, second $(-26.2 \%)$, third $(-26.2 \%)$ and fourth minutes $(-24.5 \%)$ and in $-\mathrm{dF} / \mathrm{dt}$, reduction at the first $(-36.3 \%)$ and second minutes $(-35.9 \%)$ compared to CG.

According to Henry et al, [26], the lipid composition of the rat skeletal muscle cell membrane is highly responsive to increases in n-3-PUFA consumption. The increase in DHA incorporation in the membrane is associated with an increase in resistance to muscular fatigue, and the type II fibers incorporate higher percentages of DHA than type I fibers, which may justify the increase in the fatigue resistance observed.

During exercise, fast twitch fibers are recruited at high intensities and muscle glycogen is the major energy source for ATP synthesis in these fibers [14]. A common adaptation promoted by interval training in fast twitch fibers is an increase in intramuscular glycogen stores [20]. The existence of a glycogenolytic complex, composed of glycogen particles, enzymes and regulatory proteins associated to the SR is related. It is suggested that this complex play a role in the regulation of intracellular $\mathrm{Ca}^{++}$levels and consequently in contractile activity [27].

Chin \& Allen [28] showed that muscle strength and intracellular $\mathrm{Ca}^{++}$levels are associated with the glycogen content in the muscle. Stammers et al, [29] argue that reduced muscle glycogen stores reduce SR activity, decreasing the rate of $\mathrm{SR} \mathrm{Ca}^{++}$release and reuptake, affecting the speed of contraction and relaxation. Our results may indicate that SLO supplementation probably alters the EDL muscle phenotype to a more oxidative profile, decreasing muscle glycogen content and altering the expression of proteins involved with the $\mathrm{Ca}^{++}$cycle, justifying the decreased contractility observed in SG.
No differences were observed in the contractile parameters analyzed in the soleus muscle between groups. Histochemical evidence suggests that exercise does not change the percentage of type I fibers [24]. However, the adaptation to exercise training may increase the dephosphorylation of Myosin Light Chain Slow (MLC2s) in contrast to Myosin Light Chain Fast (MLC2f), which reduces the sensitivity of the myofilaments to $\mathrm{Ca}^{++}$, reducing the cross-bridge cycle velocity and the speed of contraction [30], not observed in our data. This result may indicate that the training protocol and/or the SLO supplementation did not generate specific adaptations in the soleus muscle.

Based on our findings, we suggest further studies to determine if athletes or recreational practitioners of physical activities whose goal is to increase strength, power and muscle hypertrophy should use this kind of substance, since type II fibers are those that mainly adapt to force stimuli and could, thus, reduce their performance.

\section{Conclusion}

There is a shortage of data regarding exercise, SLO and contractile muscle mechanics. Our results reveal that the SLO consumption affects the contractile kinetics of the EDL muscle and, probably, muscles with glycolytic characteristic, reducing its contractile performance and increasing fatigue tolerance, without optimizing the contractility or the resistance of muscles with oxidative characteristics.

\section{Acknowledgments}

We thank Capes for the financial support, Naturalis Alimentos Naturais Ltda for kindly donating the SLO, Nelson Tomasin Jr for reviewing the writing of this paper and Alexandro Tamanini for the help during this project. This work was partially funded by the Grant - Pesquisa Básica e Aplicada edital Universal from the Fundação Araucária (\#09/2016).

\section{References}

1. Gleeson MM. Immune function in sport and exercise. J Appl Physil. 2007;103(2);693-9. 
2. Simopoulos AP. Omega-3 fatty acids and athletics. Curr Sports Med Rep. 2007;6(4):230-6.

3. Mitre R, Etienne M, Martinais S, Salmon H, Allaume P, Legrand $\mathrm{P}$, et al. Humoral defence improvement and haematopoiesis stimulation in sows and offspring by oral supply of shark-liver oil to mothers during gestation and lactation. Br J Nutr. 2005;94(5):753-62.

4. Belo SRB, Iagher F, Bonatto SJ, Naliwaiko K, Calder PC, Nunes EA, et al. Walker-256 tumor growth is inhibited by the independent or associative chronic ingestion of shark liver and fish oil: a response linked by the increment of peritoneal macrophages nitrite production in Wistar rats. Nutr Res. 2010;30(11):770-6.

5. Rodacki CDLN, Rodacki ALF, Coelho I, Pequito D, Krause M, Bonatto S, et al. Influence of fish oil supplementation and strength training on some functional aspects of immune cells in healthy elderly women. $\mathrm{Br}$ J Nutr. 2015;114(1):43-52.

6. Molfino A, Gioia G, Fanelli FR, Muscaritoli M. The role for dietary omega-3 fatty acids supplementation in older adults. Nutrients. 2014;6(10):4058-73.

7. Da Boit M, Hunter AM, Gray SR. Fit with good fat? The role of n-3 polyunsaturated fatty acids on exercise performance. Metabolism. 2017;66:45-54.

8. Venugopal V, Kumaran AK, Sekhar Chatterjee N, Kumar S, Kavilakath S, Nair JR, et al. Biochemical characterization of liver oil of echinorhinus brucus (bramble shark) and its cytotoxic evaluation on neuroblastoma cell lines (SHSY-5Y). Scientifica. 2016;2016: 6294030.

9. Rose DP, Connolly JM. Omega-3 fatty acids as cancer chemopreventive agents. Pharmacol Ther. 1999;83(3):217-44.

10. Tsuchiya Y, Yanagimoto K, Nakazato K, Hayamizu K, Ochi E. Eicosapentaenoic and docosahexaenoic acids-rich fish oil supplementation attenuates strength loss and limited joint range of motion after eccentric contractions: a randomized, double-blind, placebocontrolled, parallel-group trial. Eur J Appl Physiol. 2016;116(6):1179-88.
11. Liu Y, Chen F, Odle J, Lin X, Zhu H, Shi H, et al. Fish oil increases muscle protein mass and modulates Akt/FOXO, TLR4, and NOD signaling in weanling piglets after lipopolysaccharide challenge. J Nutr. 2013;143(8):1331-9.

12. Smith G, Julliand S. Fish oil-derived n-3 PUFA therapy increases muscle mass and function in healthy older adults. Am J Clin Nutr. 2015;102(1):115-22.

13. Calderón JC, Bolaños P, Caputo C. The excitationcontraction coupling mechanism in skeletal muscle. Biophys Rev. 2014;6(1):133-60.

14. Frontera WR, Ochala J. Skeletal muscle: a brief review of structure and function. Calcif Tissue Int. 2015;96(3):183-95.

15. Röckl KSC, Hirshman MF, Brandauer J, Fujii N, Witters LA, Goodyear LJ. Skeletal muscle adaptation to exercise training: AMP-Activated protein kinase mediates muscle fober type shift. Diabetes. 2007;56(8):2062-9.

16. Delp MD, Duan C. Composition and size of type I , IIA, IID / X, and IIB fibers and citrate synthase activity of rat muscle. J Appl Physiol. 1996;80(1):261-70.

17. Wisløff U, Helgerud J, Kemi OJ, Ellingsen Ø. Intensity-controlled treadmill running in rats: Vo2 max and cardiac hypertrophy. Am J Physiol Circ Physiol. 2001;280(3):H1301-10.

18. Haram PM, Kemi OJ, Lee SJ, Bendheim MØ, Al-Share QY, Waldum HL, et al. Aerobic interval training vs. continuous moderate exercise in the metabolic syndrome of rats artificially selected for low aerobic capacity. Cardiovasc Res. 2009;81(4):723-32.

19. Ryall JG, Gregorevic P, Plant DR, Sillence MN, Lynch GS, James G. Beta 2-Agonist fenoterol has greater effects on contractile function of rat skeletal muscles than clenbuterol. Am J Physiol. 2002;283(6):1386-94.

20. Coffey V, Hawley J. The molecular bases of training adaptation. Sports Med. 2007;37(9):737-63. 
21. Stephenson EJ, Camera DM, Jenkins TA, Kosari S, Lee JS, Hawley JA, et al. Skeletal muscle respiratory capacity is enhanced in rats consuming an obesogenic Western diet. Am J Physiol Metab. 2012;302(12):E1541-9.

22. Nakamura MT, Yudell BE, Loor JJ. Regulation of energy metabolism by long-chain fatty acids. Prog Lipid Res. 2014;53:124-44.

23. Lin J, Wu H, Tarr PT, Zhang CY, Wu Z, Boss O, et al. Transcriptional co-activator PGC-1a drives the formation of slow-twitch muscle fibre. Nature. 2002;418(6899):797-801.

24. Fitts R, Widrick J. Muscle mechanics: adaptations with exercise training. Exer Sport Sci Rev. 1996;24:427-73.

25. Periasamy M, Maurya SK, Sahoo SK, Singh S, Reis FCG, Bal NC. Role of SERCA pump in muscle thermogenesis and metabolism. Compr Physiol. 2017;7(3):879-90.

26. Henry R, Peoples GE, McLennan PL. Muscle fatigue resistance in the rat hindlimb in vivo from low dietary intakes of tuna fish oil that selectively increase phospholipid n-3 docosahexaenoic acid according to muscle fibre type. Br J Nutr. 2015;114(6):873-84.
27. Ørtenblad N, Nielsen J, Saltin B, Holmberg HC. Role of glycogen availability in sarcoplasmic reticulum Ca2+ kinetics in human skeletal muscle. J Physiol. 2011;589(3):711-25.

28. Chin ER, Allen DG. Effects of reduced muscle glycogen concentration on force, $\mathrm{Ca} 2+$ release and contractile protein function in intact mouse skeletal muscle. J Physiol. 1997;498(1):17-29.

29. Stammers AN, Susser SE, Hamm NC, Hlynsky MW, Kimber DE, Scott Kehler D, et al. The regulation of sarco (endo) plasmic reticulum calcium-ATPases (SERCA). Can J Physiol Pharmacol. 2015;93(10):843-54.

30. Munkvik M, Lunde PK, Sejersted OM. Causes of fatigue in slow-twitch rat skeletal muscle during dynamic activity. Am J Physiol Regul Integr Comp Physiol. 2009;297(3):R900-10.
Received in 01/21/2019

Recebido em 21/01/2019

Recibido en 21/01/2019

Approved in 07/01/2020

Aprovado em 07/01/2020

Aprobado en 07/01/2020 